\title{
Pensions During the Crisis: Impact on Retirement Income Systems and Policy Responses
}

\author{
Edward Whitehouse \\ OECD, rue André Pascal 2, Paris 75775 Paris Cedex 16, France. \\ E-mail: Edward.Whitehouse@oecd.org
}

The financial and economic crisis has had a profound impact on economies and societies, and pension systems are no exception. This paper illustrates the impact of the financial crisis on private pension schemes and of the wider economic crisis on both private and public retirement income provisions. The analysis shows that no pension scheme and no country is immune from the effects of the crisis. Policy responses to the crisis are explored: both short-term mitigation and addressing long-term, structural problems that have been highlighted and exacerbated by current financial and economic difficulties.

The Geneva Papers (2009) 34, 536-547. doi:10.1057/gpp.2009.25

Keywords: pensions; reforms; crisis; policy response; retirement

\section{Introduction}

The financial and economic crisis has never been far from the headlines for the last 18 months and rarely have other stories pushed its impact on people off the front pages. ${ }^{1}$ The crisis has had a particularly profound effect on pension systems and retirement incomes, which are explored in this paper.

The financial part of the crisis has dealt a heavy blow to private pension funds; in the calendar year 2008, their investments lost 23 per cent of their real value on aggregate in the Organisation for Economic Co-operation and Development (OECD) countries. This is the equivalent of a heady U.S.\$5.4 trillion. It means that many people have lost a substantial amount of their retirement savings, from pension plans and other assets.

However, the financial crisis is growing into an economic crisis. The OECD's recent economic forecast for its 30 member countries predicts a fall in gross domestic product (GDP) in 2009 of 4.4 per cent and stable output in 2010. Unemployment in the OECD reached a low point of 5.6 per cent in 2007 , increasing to 6.0 per cent in 2008, with further rises to 8.4 per cent in 2009 and 9.9 per cent in 2010.

\footnotetext{
${ }^{1}$ Edward Whitehouse works in the social policy division of the Organisation for Economic Co-operation and Development (OECD). Rafal Chomik, on secondment to the OECD from the Department of Work and Pensions in the United Kingdom, provided valuable research assistance. The contribution of other colleagues at the OECD to the analysis is also gratefully acknowledged: Pablo Antolín, Anna D'Addio, Martine Durand, John P. Martin, Mark Pearson, Monika Queisser, Andrew Reilly, Fiona Stewart and Juan Yermo. The views expressed are those of the author alone and do not necessarily reflect the official stance of the OECD or of the governments of its member countries.
} 
This means that public pension schemes are also affected. Unemployment and lower earnings will reduce the contribution revenue of Pay-As-You-Go (PAYG) pension systems, making it more difficult for these systems to deliver pension benefits. Some public pension reserve funds have also suffered major losses on their investments.

Therefore, no country and no pension scheme is immune from the impact of the financial and economic crisis. This brief survey ${ }^{2}$ begins by analysing which countries are most affected.

\section{Impact on pension systems}

Figure 1 shows pension funds' real investment returns in 2008 for countries where these funds are significant. There is considerable variation around the aggregate loss of 23 per cent for the OECD as a whole. The United States, which accounts for around a half of all private-pension assets in OECD countries, showed the third largest decline: around 26 per cent. Only Ireland and Australia, with losses of 38 and 27 per cent, showed a worse investment performance. In another five countries - Belgium, Canada, Hungary, Iceland and Japan - real investments fell by more than 20 per cent. At the other end of the scale, losses were only around 10 per cent in Germany, the Slovak Republic, Norway, Spain and Switzerland. They were smaller still in the Czech Republic and Mexico.

The explanation for these differences is relatively straightforward. In 2008 as a whole, world stock markets (as measured by the Morgan Stanley Capital International (MSCI) index) fell by nearly a half, whereas the world government bond index (Citigroup) increased by around 7 per cent. Property markets in many OECD economies weakened, in some cases dramatically. These assets, along with corporate bonds and deposits, account for nearly all pension funds' investments. However, pension funds' portfolios differ significantly between countries, and it is this variation that accounts for different performance.

Figure 2 plots pension fund investment returns (from Figure 1) against the proportion share of equities. The latter is measured for 2007 to give a picture before the financial crisis hit: equities' portfolio share will obviously have declined along with stock markets. There is clearly a very strong relationship. Ireland has both the largest losses and the largest proportion invested in equities: two-thirds of the portfolio. Equity shares and investment losses were also relatively high in Australia and the United States. Canada, Japan and the United Kingdom, all with relatively large equity holdings of 50 per cent or more of assets, did not perform as badly.

Most of the countries with the smallest losses in 2008 had bond-dominated portfolios; the equity share was just 6-12 per cent in the Czech and Slovak Republics, Germany and Mexico, for example. However, it is important to bear in mind that over the long term, equities have delivered larger (although riskier) returns (see below).

\footnotetext{
${ }^{2}$ The chapter on "Pension systems during the financial and economic crisis" in OECD (2009) provides a more comprehensive treatment.
} 


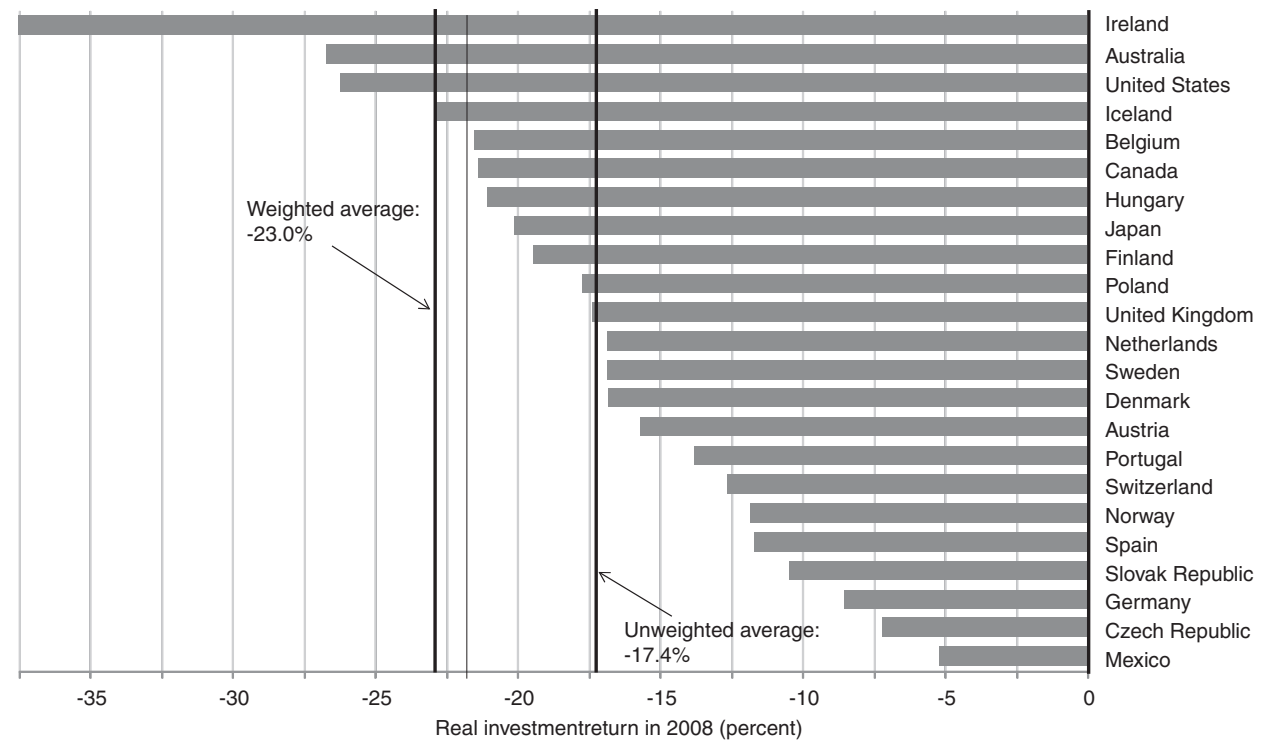

Figure 1. Pension funds' real investment returns in 2008. Source: OECD (2009), Figure 1.3.

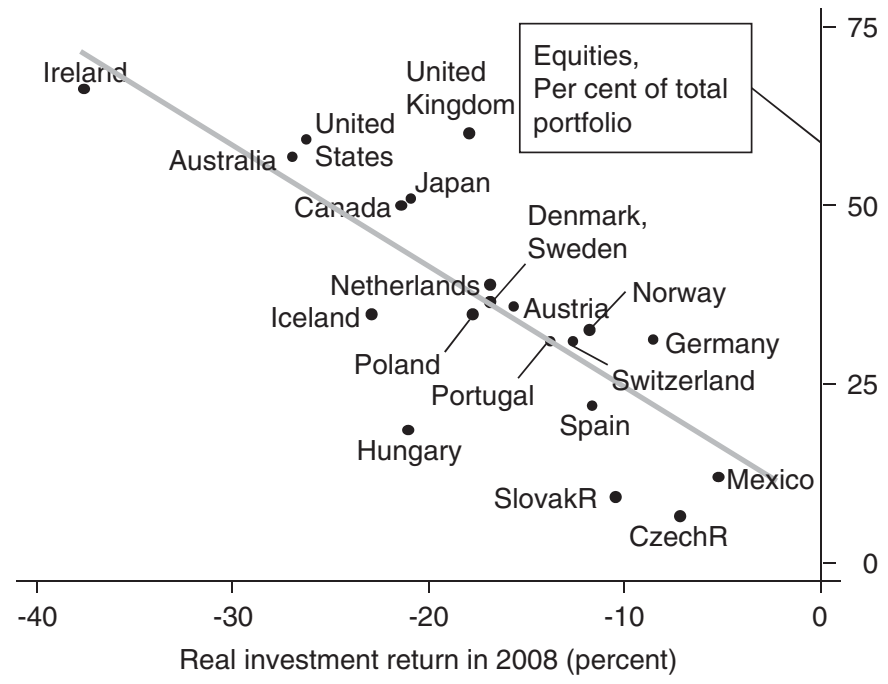

Figure 2. Pension funds' real investment returns in 2008 and equity exposure in 2007. Source: OECD (2009), Figure 1.4.

The scale of the impact of the crisis on individuals' incomes in old age depends on the role that private pensions play in providing retirement incomes. Moreover, many people save for retirement outside of "pension" plans, and these investments may too have suffered losses. Figure 3 shows the proportion of retirement incomes that come 


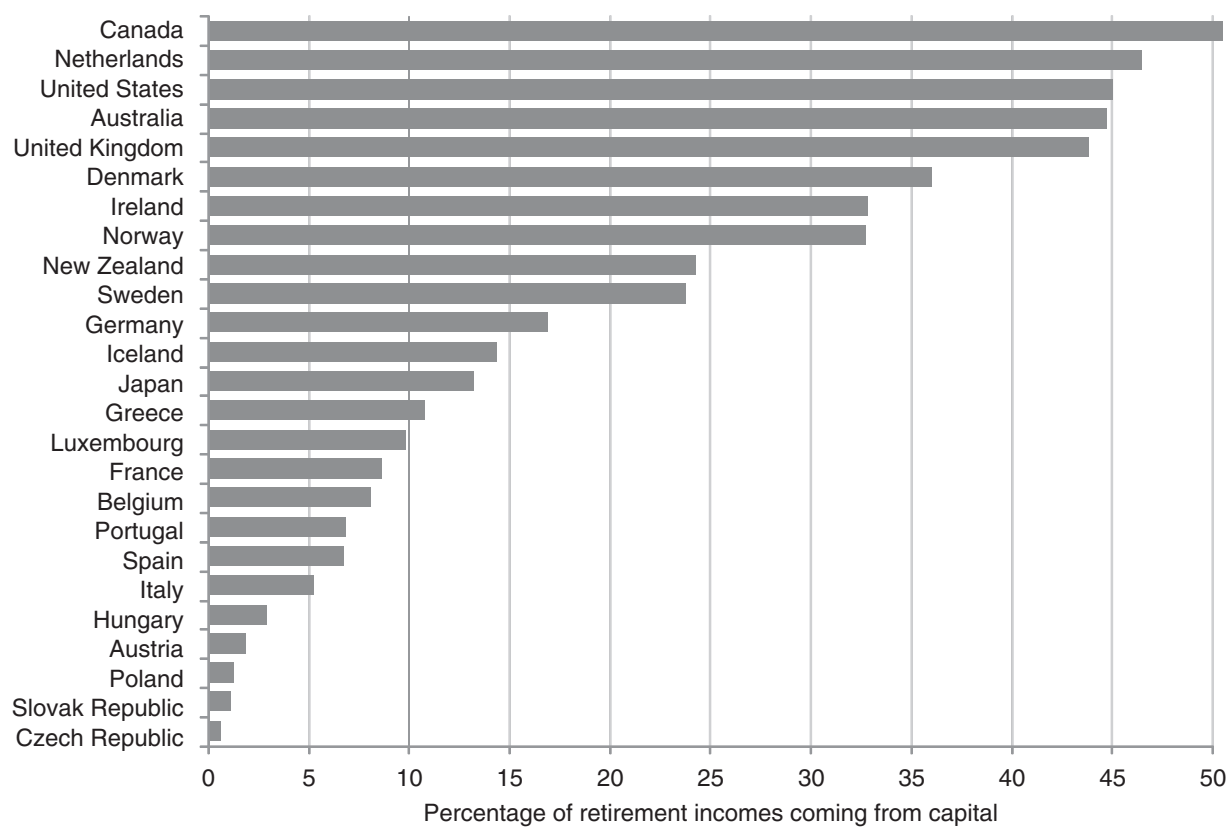

Figure 3. Role of private savings in retirement incomes in mid-2000s. Source: OECD income distribution database. See OECD (2008) and the chapter "Incomes and poverty in old age" in OECD (2009) for more details.

from "capital", which mainly comprises private pensions but also includes other savings. Since the focus is on retirement incomes, the percentage from capital is calculated excluding income from work (earnings and self-employment income). There are five countries where capital provides $40-50$ per cent of retirement incomes: four English-speaking countries plus the Netherlands.

The financial part of the crisis has, therefore, had most impact in countries where private pensions already play a major part in providing old age incomes and where private-pension assets are invested heavily in equities.

But, private pensions are a significant part of current workers' retirement provision in more OECD countries than the chart suggests. A number now have mandatory private pensions. For today's younger workers, private pensions are expected to provide around a third of retirement incomes in Hungary, half in Poland, 60 per cent in the Slovak Republic and three quarters in Mexico. Although the impact of the current crisis in these countries will be relatively minor, it highlights the need for resilience to a future crisis.

\section{Impact on individuals}

The most important determinant in the degree of impact of the crisis on pensions is the age of the individual. 


\section{Younger and prime age workers}

Most younger workers are little affected by the financial crisis because their accumulations of retirement savings are small. In the United States, for example, 25-34 year-old people' balances in their private pension plans increased by nearly 5 per cent on average in 2008, according to the Employee Benefit Research Institute. This is because their new contributions outweighed investment losses. Although they may suffer from the effects of the economic crisis on the labour market, they have 30 years or more in which to recoup losses and offset gaps in contributions.

Similar arguments apply to prime-age workers, though the effect on their private retirement savings (in pensions and other assets) is greater. In the United States, account balances for 35-44-year-old people (with the same 5-9 years' tenure in the plan as the 25-34-year-old people) fell by nearly 15 per cent. The decline for $45-54-$ year-old people was nearly 18 per cent. Nevertheless, prime age workers still have time for asset values to recover. Also, their jobs tend to be safer in downturns than those of younger or older workers.

\section{Pensioners}

Those already retired will, in general, be unaffected by the crisis. The impact of the economic crisis on labour markets is of no direct significance to them. Most are also protected against the losses affecting private pensions even where these are a significant source of retirement income because occupational plans and annuity providers hold assets to back promises to pay a certain pension. There are two exceptions.

The first affects people in defined contribution pensions. These schemes provide retirement support by the accumulation of pension contributions and investment returns. The issue is how people use the money during retirement. Many retirees are protected from the crisis because they bought an annuity on retirement, locking in earlier investment gains and benefitting from life-long pension payments. But, many did not buy an annuity or deferred doing so. Some, particularly in Australia and the United States, had a lot of equities in their portfolios and so their losses have been large. Similarly, people who held assets, including houses, outside of pension plans might have lost substantial amounts.

The second exception, where retirees are affected by the crisis, is in countries where pensions in payment are subject to automatic adjustments linked to pension scheme finances (see below).

\section{Workers nearing retirement}

Older workers - those close to retirement - are the group most acutely affected by the economic and financial crisis. They are often among the first to lose their jobs during a downturn and among the most vulnerable to long-term unemployment. Unemployment or early retirement can permanently reduce their old age incomes due to an incomplete contribution history. People in this age group do not have much time to 
wait for markets to recover and losses to be recouped. Even postponing retirement may only allow them to offset part of their losses.

As with retirees, the impact of the financial crisis on retirement incomes depends on how assets were invested. Some older workers moved their investments towards less risky assets as retirement approached. But most did not. In the United States, for example, nearly 45 per cent of 55-65-year-old people held more than 70 per cent of their private pension assets in equities, according to the Employee Benefit Research Institute. This is only a little below the 50 per cent with such a portfolio under the age of 55 years. In Australia, more than 60 per cent of people stick with the default investment option of their private plan, and equities typically make up around 60 per cent of this portfolio.

The financial crisis has a direct impact on retirement incomes for people with defined contribution plans. In Iceland, the Netherlands and Switzerland, private pensions are defined benefit (or a variant); the value of the pension depends on individual earnings and the number of years covered by the scheme. In Canada, Ireland, Sweden, the United Kingdom and the United States, private pensions were traditionally also defined benefit. There has been a shift towards defined contribution plans in all these countries. Still, many or most older workers in these countries will get all or most of their pensions from defined benefit schemes.

In theory, pensions in these schemes should be paid regardless of pension fund investment performance. However, investment losses have hit these funds hard. The yardstick is the "funding ratio" - the assets of the scheme relative to its liabilities to pay current and future liabilities. In Ireland, the United Kingdom and the United States, funding ratios for defined benefit plans have fallen from 110-120 to around 75 per cent. Ratios have also declined in Belgium, Finland and Switzerland, but remain above 100 per cent.

In the Netherlands, defined benefit schemes are cutting back on benefit adjustments, which are generally indexed. This affects retirees' benefits and accrued pension rights of workers. Elsewhere, the crisis is accelerating the shift from defined benefit to defined contribution plans. For example, some schemes in the United Kingdom and the United States, already closed to new members, are stopping additional accruals for existing members. Also, defined contribution provision is being wound back as a series of employers have announced temporary suspension of their contributions.

\section{Effect of automatic stabilisers}

Most public retirement income programmes pay the same benefit regardless of the outcome of private pensions, but some do not. In Australia and Denmark, most of today's retirees (65 and 75 per cent, respectively) receive resource-tested benefits. These entitlements increase if private pensions deliver lower retirement incomes. In Australia, a dollar less of private income means 60 cents more public pension. A large share of older people - 20-35 per cent - receives means-tested benefits in Canada, Ireland and the United Kingdom as well. These act as "automatic stabilizers", so that some or most retirees do not bear the full brunt of the financial crisis. 
Tax also works as an automatic stabilizer; as private pensions and other savings deliver a smaller income, less tax is due so the decline in net pensions is smaller than the fall in asset values. Of the countries where private retirement savings are an important source of old age income, taxes act as a significant automatic stabiliser in Denmark, Norway and Sweden. In contrast, only a minority of retirees pay taxes in Australia, Canada, Ireland, the United Kingdom and the United States, so the stabilising effect is limited to richer retirees.

\section{Policy responses}

The crisis has prompted a range of changes to pension systems. Some of these were designed to tackle structural problems with retirement income provisions that were highlighted and exacerbated by the crisis. Some were more immediate measures, such as one-off payments to older people as part of economic stimulus packages. These range from U.S.\$140-180 in Greece to over U.S.\$1,000 in Australia. The United Kingdom and the United States have also made one-off payments.

\section{Stronger old age safety nets}

These and other countries have also made longer-term improvements in old age benefits, which, like one-off payments, are targeted to the elderly poor. Finland proposed the biggest change: from 2011, a new safety net old age income 23 per cent higher than the existing benefit. Increases to pensions of 11 per cent in Australia and 6 per cent in Spain beyond existing indexation rules have also been announced. Belgium, France, Korea and the United Kingdom have adopted similar policies.

Of these, Australia and Korea have among the highest proportions of older people living in poverty in OECD countries; the old age poverty rate is also above average in Spain. Most of these measures are well targeted on existing social problems. However, some of them aimed at current retirees do not address the group affected most by the crisis - workers near retirement age.

There are other countries where old age safety nets are a concern. Figure 4 shows that full career workers with low earnings (half the average) would have a retirement income of around 25 per cent or less of average earnings in Germany, Japan and the United States. Once a period of early retirement or long-term unemployment (as a result of the economic crisis) is factored in, people with low wages are at significant risk of very low incomes in their old age.

\section{Early access to retirement savings}

Another set of measures aims at stimulating the economy through the pension system. Individuals in Denmark and Iceland, for example, will be allowed early access to their pension savings. The risk is that these people will be left short of money when they retire. In both these countries that is unlikely, the access is limited to accumulations well above that needed to provide a comfortable retirement. 


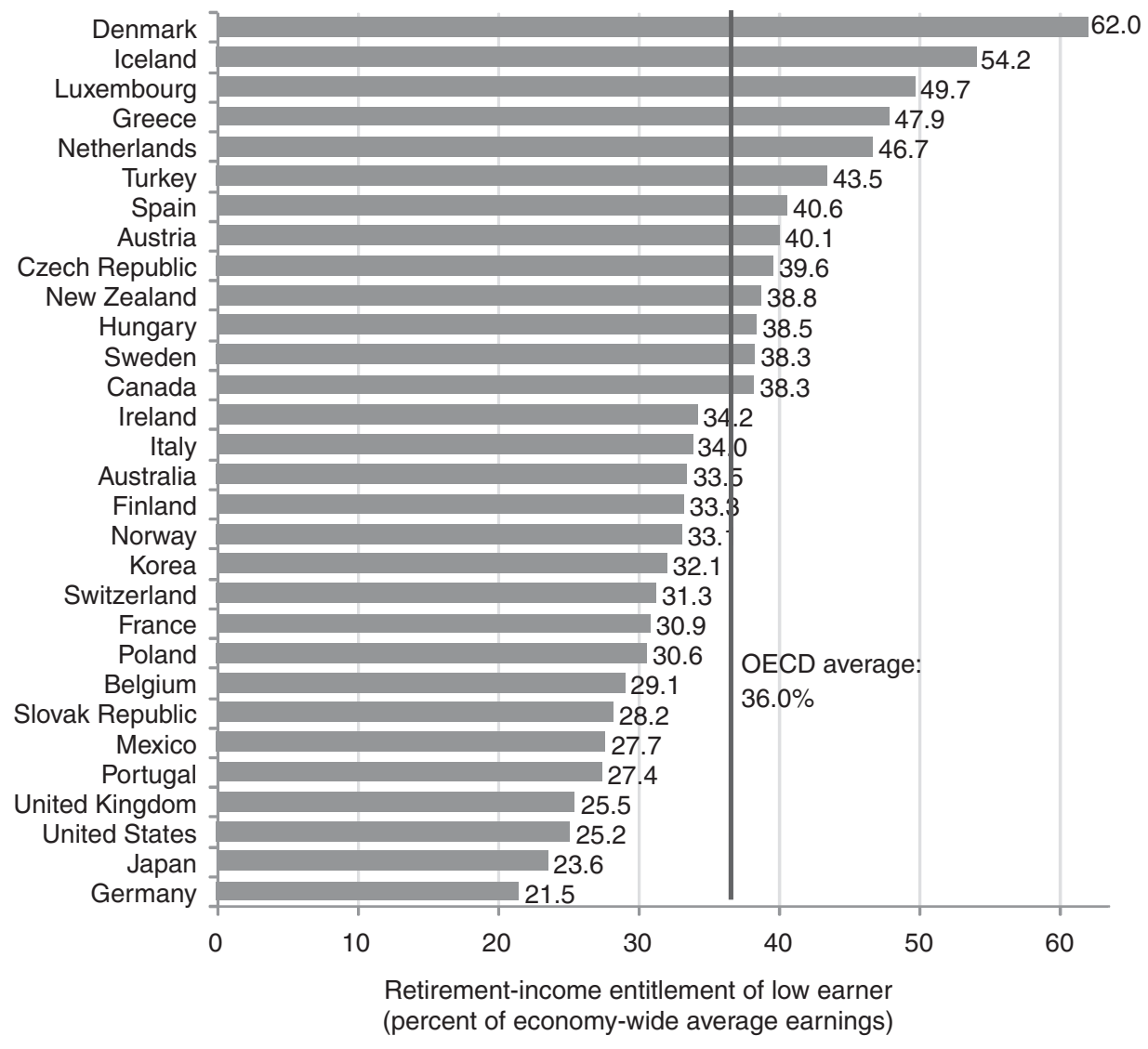

Figure 4. Old age safety nets for low earners. Source: OECD pension models; see "OECD Pensions at a Glance" OECD (2009).

Australia lets people use pension savings in cases of severe hardship - for example, to avoid foreclosure on their homes. And workers in the United States have long-taken advantage of loans from their private pensions, which are mostly repaid, with interest, to avoid tax penalties.

The effectiveness of these policies is limited because people with higher retirement savings are less likely to get into financial difficulties. Care is needed to ensure that people do not unduly threaten their retirement incomes, but early access to pension savings should not be off the menu.

\section{Bailing out pension accounts}

Defined benefit schemes are already covered in the United Kingdom and the United States by programmes that are financed by levies on occupational plans, but the government acts as an implicit guarantor. 
With defined contribution plans, the case for intervention rests on the design of the pension system. It is weaker where public provision is sizeable and where people have investment choices. In contrast, governments may have a duty to help where defined contribution pensions are mandatory rather than voluntary, and where annuitisation is obligatory.

A direct bail out - paying money into pension accounts - could be very costly. There is also a risk of moral hazard - encouraging people to invest more riskily. For these reasons, ad hoc guarantees of investment returns or compensation for losses should be avoided.

A bail out would make most sense for those close to pension age. But, this may discriminate against those younger than the cutoff age and retirees who annuitised only recently. The only example of a direct bail out is in Israel. However, this scheme is very limited in scope (covering only any losses since November 2008) and costs are spread over 13 years.

Governments should rely on public retirement income schemes to ensure against old age poverty for a generation of retirees. Paying compensation as a public benefit spreads the cost across the retirement of the individuals involved, reduces political tensions and reduces moral hazard.

\section{Investments and risks}

Pensions are long-term investments and it would be short-sighted to base decisions on last year alone, when stock markets lost nearly half their value but government bonds showed positive returns.

Based on a quarter century's data on performance of equities and bonds, the OECD has simulated real investment returns over the 45-year horizon of retirement savings. The results (in Figure 5) show a range of portfolios across the horizontal axis - from pure bonds at the left to pure equities at the right. The white line shows median returns half the time returns will be above this level, and half the time below. For a "balanced" portfolio - half each in equities and bonds - the median return is 7.3 per cent above inflation. It is higher for a portfolio of equities (8.9 per cent) and lower for bonds (5.2 per cent). The shaded areas of the fan show the likelihood of different outcomes, based on past experience. With a balanced portfolio, real returns are expected to be 5.5 per cent a year or less 10 per cent of the time. Equally, they are projected to exceed 9.0 per cent a year and also 10 per cent of the time. Equities clearly give a higher return at the price of greater risk.

For all but the most risk averse, equities should remain part of people's retirement savings. But, there is one strategy that can reduce risk without undue sacrifice of returns. "Life cycle" investing involves a move from riskier assets to less risky assets. Governments should at least encourage people to choose this strategy, but it may be necessary to go further, and make life cycle investment the default. This would put investments for most people on automatic pilot while preserving choice for the minority who wish to manage their investments actively.

Mexico and the Slovak Republic have investment choice in mandatory private pensions, with riskier options unavailable to older workers. But, for the moment, even 


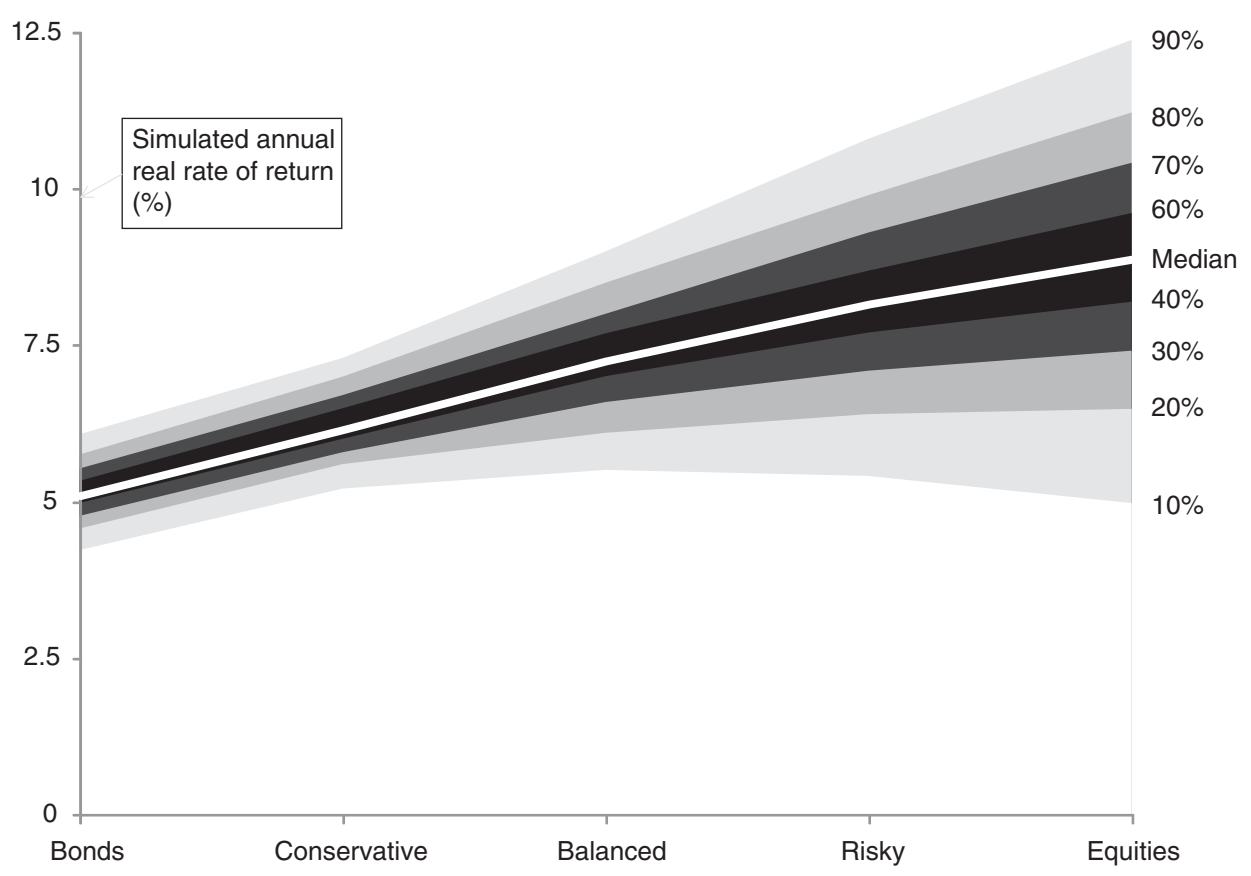

Figure 5. Investment risk and pensions. Source: Whitehouse et al. (2009).

the riskier funds tend to hold less than 20 per cent of assets in equities. Poland will also introduce investment choice and life cycle investing. In the United States, life cycle funds have not had much success. Although two-thirds of plans offer them as a choice, only around a quarter of members hold these funds and they account for just 7 per cent of assets. This proportion might increase as new laws let plans automatically enrol people into life cycle funds. But simply ensuring that life cycle options are offered has not provided broad coverage.

\section{Regulating defined benefit schemes}

The financial crisis has also had a major effect on defined benefit, occupational pension schemes. In Ireland, the United Kingdom and the United States, for example, average funding ratios - a scheme's assets relative to its liabilities in the form of current and future pensions - have fallen from over 100 (a surplus) to around 75 per cent (a large deficit). The financial position has also worsened in other countries, such as Belgium, Finland, the Netherlands and Switzerland, with significant defined benefit and occupational provision.

A common response to the current crisis has been to extend the "recovery periods" during which defined benefit pension plans must restore their solvency. This makes sense in a recessionary environment, where profitability is declining and credit is restricted, so forcing employers to increase contributions to underfunded pensions 
would only make matters worse. Canada, Finland, Ireland, the Netherlands and Norway have all suspended some solvency requirements temporarily to allow asset values to recover. However, it is critical that these policies do not become a permanent weakening of funding regulations, which would put workers' incomes in retirement at risk.

\section{Further challenges: pension systems in the crisis and beyond}

The projected rise in unemployment in OECD countries - from less than 6 per cent of the workforce to 10 per cent in 2010 - will hit older workers hard. In past recessions, many governments had relaxed the rules or policing of early retirement and disability benefits. The aims were to protect incomes of older workers losing their jobs and limit increases in official unemployment. Whatever the short-term benefits, the mediumand long-term impact on labour markets was negative. After the early 1980s recession, unemployment (especially long-term unemployment) persisted well after economies had recovered and these policies were difficult to unwind.

This time, there is little evidence yet of governments repeating these mistakes. But, unemployment tends to lag changes in economic output and so is expected to continue growing for some time. The word "yet" is the operative one; vigilance is required to ensure that the danger of using early retirement and disability benefits to disguise unemployment is averted.

\section{Backtracking on pension reforms}

More worrying is evidence of reversal of pension reforms. The Slovak Republic has encouraged people to opt back into the state pension scheme rather than diverting part of their contributions to private, defined contribution plans. When this was first offered, only 6 per cent of members of the private plans chose to switch back. However, it is no longer compulsory for labour market entrants to join the private funds and the public scheme is the default option. This is an irreversible, once-in-alifetime decision that will have long-term effects on the retirement incomes of new labour market entrants.

The motivation for this change is short-term fiscal problems. Some 60 per cent of workers actively chose to join the new private pensions at the time of reform. This was many more than expected, and the diversion of contributions from the public to the private scheme has left a hole in the government's finances. A more sensible way of alleviating short-term fiscal problems is temporarily to reduce the contribution going into private pensions. Although no OECD country has adopted this strategy, it is likely to be used in Estonia, Latvia and Lithuania, for example.

\section{Automatic benefit adjustments}

Some OECD countries - Canada, Germany and Sweden - have automatic adjustments to pension entitlements to reflect the state of the schemes' finances. These work in a similar way to adjustments in occupational plans in the Netherlands (see above). 
The sustainability adjustment in Germany links pensions to the dependency ratio pensioners relative to contributors. But the government has overridden the adjustment for 2 years running, increasing entitlements above what would have resulted from the sustainability factor, affecting both pensions in payment and the accrued rights of current workers.

The balance mechanism in Sweden compares the assets of the fund (investments plus future contributions) with the liabilities (current and future pensions). The ratio between the two has fallen to 96.7 per cent; at the first time, it was under 100 per cent. Under the rules, pensions in payment and accrued rights should be cut next year to restore the balance. In practice, it is likely that cuts will be postponed.

Automatic adjustment mechanisms were introduced as a way of ensuring long-term financial sustainability of pension systems in the face of population ageing. Recent experience suggests that their design needs a re-think. It does not seem sensible to reduce benefits in a pro-cyclical way, taking money out of the economy when it is weak. However, cuts needed to restore financial health must be postponed and not cancelled with temporarily higher benefit levels clawed back when economies recover.

\section{Conclusion}

The financial and economic crisis means that the short-term pressures on governments to act are huge. Nevertheless, the long-term challenges for pension systems - from demographic change and population ageing - have not gone away. If anything, they have been underlined and exacerbated by the financial and economic crisis. The impact of the economic and financial crisis on retirement incomes will be painful for many, in both public and private pension schemes. But, in terms of pension policies, the effects of the crisis are dwarfed by the challenge of ageing.

The crisis has also brought investment risk to the fore of many people's minds, but it is one of many economic, demographic, financial and social uncertainties in pension systems. One of the key lessons is that risk cannot be eliminated, it can only be reduced by diversifying retirement income provision. The current crisis reinforces the message OECD (1998) that old age security is best maintained through diversified pension provision.

\section{References}

OECD (1998) Maintaining Prosperity in an Ageing Society, Paris: OECD.

OECD (2008) Growing Unequal? Income Distribution and Poverty in OECD Countries, Paris: OECD. OECD (2009) Pensions at a Glance: Retirement Income Systems in OECD Countries, Paris: OECD.

Whitehouse, E.R., D'Addio, A.C., Chomik, R. and Reilly, A. (2009) 'Two decades of pension reform: What has been achieved and what remains to be done?' The Geneva Papers on Risk and Insurance - Issues and Practice 34(4): 515-535.

\section{About the Author}

Edward Whitehouse heads the pensions team in the OECD's social policy division, and is the lead author of the OECD's flagship publication on retirement income systems, Pensions at a Glace. He also works with the pensions unit of the World Bank. 